\title{
Obituary
}

\section{HENRY A. MAGNUS}

Professor Magnus was a member of the Editorial Board of the Journal from 1956 until the time of his death, and it is with great grief that we report his death on 12 September 1967. He died at his desk. As Editor of the Journal, I particularly valued his opinions and his assessments of work offered which were always positive and exceptionally fair. His excellent knowledge of the literature often enabled him to provide an author with a basis for reorientating his paper and providing a vastly superior contribution. We print below an appreciation of Professor Magnus by two of his colleagues at King's College Hospital, London.

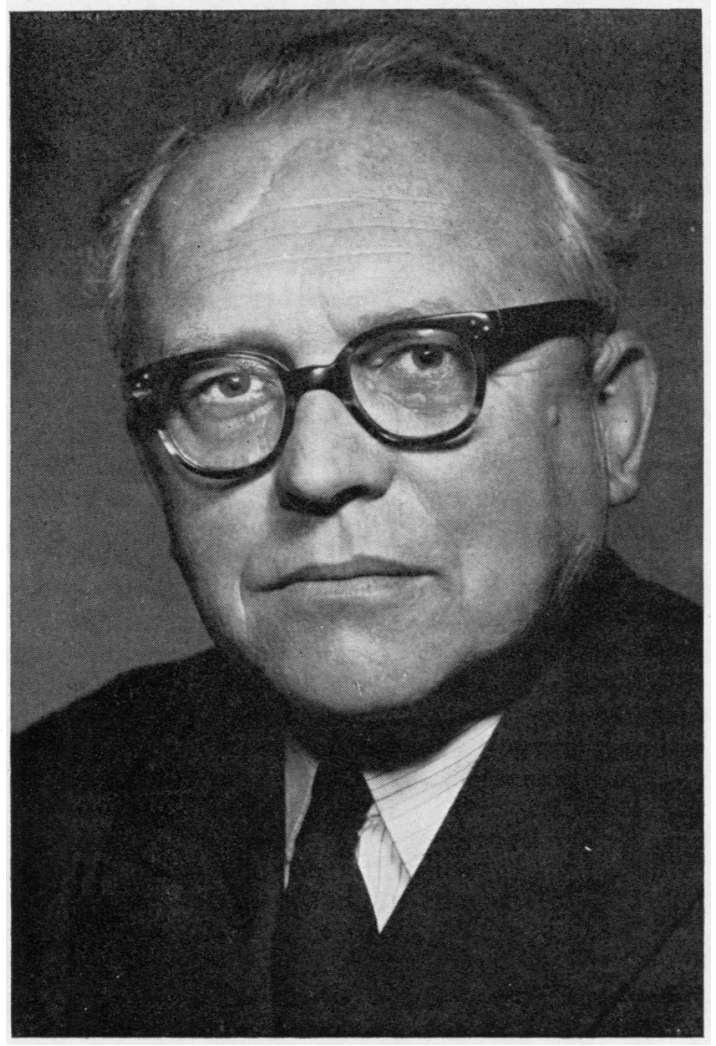

Although 'Dick' Magnus was known to have been in ill health the suddenness of his death will have come as a great shock to the many pathologists who knew him.

He had that undefinable quality which left those who met him with a memory of his personality so vivid that they would carry it for the rest of their lives. Even before he spoke his purposeful gait, his stocky build, and the powerful outline of his features prepared one for his determined and incisive manner of speech. His immense vitality and clarity of thought were factors upon which his success as counsellor, research worker, soldier, and administrator depended.

Dick's postgraduate career can be considered in three parts: his research work at St. Bartholomew's Hospital in the years before the war; his military service; and the period in which he built up the Division of Pathology at King's College Hospital. The recent addition of a Department of Experimental Pathology realized one of his most cherished ambitions, and gave him the opportunity to reestablish his interest in cancer research.

His most important experimental work was on pre-cancerous conditions in the gastric mucosa and its value was recognized by the award of a Gold Medal for his M.D. thesis by London University. Best known is his description of the gastric lesion in pernicious anaemia. His interest in gastroenterology continued throughout his life and was delightfully illustrated in his Kettle Memorial Lecture.

His research work was interrupted by the war, and, as was characteristic of the man, Dick went to France on 14 September 1939 as pathologist to the Third General Hospital. Despite a recent appendicectomy, he was in the retreat of May 1940. This experience proved useful to him in the successful evacuation of casualties during the fall of Crete. Thereafter, he was given the opportunity to develop his abilities as an administrator. By August 1944 he was Assistant Director of Pathology, Palestine and Ninth Army, and became a well-known and highly regarded figure in medical circles in the Middle East.

Soon after the war he came to King's to establish a Morbid Anatomy Department; succeeded Dr E. ff. Creed as Director of Pathology in 1947; and was elected Professor of Morbid Anatomy in the University of London in 1948. During the last 20 years he developed the present Division of Pathology from very small beginnings. He did this by his administrative capabilities which included foresight, pertinacity, and that infective enthusiasm by which he persuaded others to accept his ideas. No small part of his success was due to his great ability to grasp quickly the essentials of any problem, but much depended on the way he prepared his case; 
he never entered any committee without full possession of the facts, and a careful preparation of the presentation of his case.

These qualities made him a valued member of the Medical School Council, the Board of Studies in Pathology, and, more recently, the Board of Governors of the Hospital. He also took a great personal interest in his staff and particularly in the welfare of the technicians. From 1960 to 1964 he was President of the Institute of Medical Laboratory Technology and guided it through a very important period in its dealings with the Ministry of Health. In this difficult task his bantering good humour often did more to smooth the path than any erudite argument.

Dick's colourful personality appealed to students, and he used his dramatic sense to the full in his teaching. He drew on his own experiences and wide knowledge of medicine to make pathology a dynamic subject. His interest in the students was deep and personal and they found 'the Professor' an approachable and sympathetic man.

This interest in the individual made him an excellent examiner whose services were sought after by many professional bodies. Not only did he examine in the University of London, but also in the Colleges of Physicians, Surgeons and Pathologists, and even went as far afield as the Sudan and Ceylon.

His enthusiasm extended to his hobbies. He had a beautiful garden, and his exploits in deep sea fishing off the coast of South Cornwall were the source of many stories. Although he never drove a car, one of his treasured photographs showed him at the wheel of a steam roller while on holiday at Portscatho; there, too, he leaves a large circle of friends.

Throughout his life Dick appeared to see a dramatic side to every situation. Whether it was in describing a pathological lesion to students, recounting his misadventures while travelling as an examiner, or even in describing his own ill health. Perhaps it was this attribute which helped him to surmount the episodes of serious illness which would have incapacitated men of lesser spirit. Throughout his career, and particularly in his battles against illness, Dick had the understanding support of Kay, his wife. His devotion to her and his two sons provided the stable background on which he built his career.

To have died quietly at his desk in the Department was in keeping with his wishes and character. It is very difficult for those who worked with him and who knew him well to accept that he is no longer sitting there ready to see us if we were in difficulty, to raise our spirits with a colourful analysis of the situation, and fortify us with shrewd advice. His death has deprived King's of a valued counsellor, but much of the devoted work he gave to his hospital of adoption is of a permanent nature which will continue to make its impact for years to come.

W. M. DAVIDSON

A. C. CUNLIFFE 